GEOGRAFICKÝ ČASOPIS / GEOGRAPHICAL JOURNAL 73 (2021) 3, 283-295

DOl: https://doi.org/10.31577/geogrcas.2021.73.3.15

\title{
SOCIAL NETWORKING IN THE EVERYDAY LIFE OF STUDENT YOUTH IN THE WESTERN UKRAINE
}

\author{
Serhii Puhach*, Kostyantyn Mezentsev**, Oleksiy Gnatiuk** \\ * Lesya Ukrainka Volyn National University, Faculty of Geography, Department of Economic and Social \\ Geography, Volya Avenue 13, 43025 Lutsk, Ukraine, puhachserhiy@gmail.com \\ ** Taras Shevchenko National University of Kyiv, Faculty of Geography, Department of Economic and Social \\ Geography, Volodymyrska Street 64/13,01601, Kyiv, Ukraine, mezentsev@knu.ua, alexgnat22@ukr.net
}

Social networking in the everyday life of student youth in Western Ukraine

The emergence and intensive development of social networking services (social media) is one of the most unique phenomena of the 21 st century. Social networking has become an integral part of everyday practices. The goal of the study was to identify spatial patterns and features of the functioning and development of social networking services, as well as the practice of social networking, among young people in Western Ukraine. The research was based on a survey conducted among geography students from the universities located in the region. There are no significant intraregional fluctuations in the penetration and use of social networking services. The results revealed a sharp dominance of three social media (Instagram, Telegram and Facebook) over the others. The social life of students is characterized by multi-networking. Social networking services have a variety of uses, including the most popular like communication with friends, entertainment and reading the news. The smallest deviations from the regio-nal average values were found for communication with friends, while the biggest differences are typical for creating own content, reading the news and communicating with people abroad.

Key words: social networking service, social networking, multi-networking, penetration rate, Western Ukraine

\section{INTRODUCTION}

Modern human geography has significantly expanded its subject area. Virtual geography, geography of cyberspace, geography of the Internet and geography of social networking services have become its separate branches. The localization patterns in real space on different geographical scales, reflecting the degree of adaptation and use of the Internet, mobile phones and other communication tools and technologies, represent an important aspect of these research areas (Kellerman 2016). Therefore, it is important not only to study the outspread and use of Internet services in terms of countries and macro-regions, but also to disclose their intraregional patterns.

Internet services actively influence many aspects of social, economic and political activities of mankind. Migration, trade, job search, innovation, advertising, healthcare, social mobility, etc. today depend on social media. In turn, the functioning of social networking services (SNS) is closely linked to geographical proximity, historical ties, political boundaries and other factors. As a result, new terms related to the use of social networking services have come into everyday use. The mere process of using websites and other Internet services to communicate with other people and find new friends has received the name social networking (Cambridge Dictionary 2020). Social networking has become an integral part of everyday practices and is studied by the geography of everyday life, which focuses on the specific reactions of people in specific spatial conditions: ordinary, every- 
day actions, experiences, human interactions, etc. (Denysyk et al. 2020). All primary forms of everyday practices, such as housing, consumption, reproduction, work, leisure, education, cultural development, civic activity, mobility (Mezentsev et al. 2019) are more or less influenced by social media. In fact, proper social networking is becoming a kind of everyday practice. This is especially evident among the younger age groups.

Traditionally, empirical research of social media has been challenged by the unavailability of extensive and representative data on the use of different social networking services by certain age, social or territorial groups. Such circumstances have produced a demand for new approaches and methods of study that should allow the parallel collection of information, are independent from the decisions of the social media administrations, and available to a wide range of scientists.

University students constitute a progressive part of the youth who widely use various social networking services in their everyday practices and to a fair extent set trends for the use of social media by other social and age groups. That is why students of geographical faculties and faculties of nature and geography at the universities located in Western Ukraine were chosen as a suitable social group for this research.

At the beginning of the study, we formulated three working hypotheses:

The first hypothesis states that the penetration of social networking services into the everyday life of people within the study region has more significant age / status differences than spatial differences. Therefore the level of penetration should be similar for the entire student youth.

The second hypothesis states that the diversity of social networking services is determined by both the peculiarities of everyday practices and the local context: borderline situation, peculiarities of the settlement system, share of rural residents, etc.

The third hypothesis states that intra-regional differences in the use of social networking services by students in various areas of everyday life are most significant in terms of news reading and work / business and are significantly smaller in terms of everyday communication.

\section{LITERATURE REVIEW}

Modern society in recent decades is increasingly acquiring the characteristics of a network society. Some researchers emphasize that it is more appropriate to study social relations in terms of networks rather than totalities (Castells 1996 and Bingham 1999). According to Kellerman (2016), the geography of cyberspace consists of the geographical aspects of websites and communication platforms. According to research by Perrin (2015), the share of adults in the United States who actively use social networking services increased from $7 \%$ in 2005 to $65 \%$ in 2015 . Researchers have observed a significant increase in the impact of social media on numerous areas of human life such as work, politics and political dialogue, communication patterns around the world, as well as on ways to obtain and disseminate information about health, social life, civic activity, adolescent life, parental care, appointments and even people's stress levels (Perrin 2015). Teachers and students made extensive use of social media (predominantly Facebook and YouTube) in their educational activities, but confidentiality and integrity were identified to be 
the two biggest problems in the use of social networking services in the educational process (Moran et al. 2011).

Although geographical studies of Internet networks (including social) and virtual spaces have been developed since the late 1990s, they were sporadic, and even now studies of the Internet through the lens of cultural geography remain relatively rare (Horton and Kraftl 2014). A set of contributions have analyzed the issues of territorial distribution and spatial aspects of the functioning of certain social online services. In particular, theoretical issues of geographical research of online networks were studied by Ter Wal and Boschma (2009) and Glückler and Doreian (2016). Lengyel et al. (2015) studied the effect of distance on the intensity of connections in social networking services. Works by Menezes and Roth (2017) and Borge-Holthoefer et al. (2011) are devoted to the analysis of multiscale geographical patterns arising from the interaction of users in social media. Sui and Goodchild (2011) and Andris (2016) addressed the possibilities of integrating data from social networking services into GIS. Takhteyev at al. (2012) considered the influence of geographical distance, national borders, language and air traffic frequency on the formation of social connections on Twitter. Laniado at al. (2017) focused on the relationship between distance and the intensity of online interaction via the example of the Spanish social networking service Tuenti.

Particularly significant from a geographical point of view is a study of Facebook in the USA (Bailey et al. 2018), which proved the decisive influence of distance on the formation of social connections of network users. Moreover, it is shown that administrative boundaries continue to exist in the virtual world of social networking. Social connectedness actually repeats the contours of the administrative-territorial division, and virtual connections for the most part are duplications of existing communications in the real material world.

The use of social networking services by students of the Faculty of Geography, Babeş-Bolyai University (Cluj-Napoca, Romania), was investigated by Dulamă et al. (2015). They note the intense use of the Internet and Facebook by the students for entertainment and communication with friends, as well as for study and career growth. Dulamă et al. (2016) studied the possibilities of using Facebook for the educational process in geography and generally assessed the experience as positive, primarily due to the informality of the setting. However, they found some difficulties as well (classification of discussions, search for the necessary information, dependence on hardware and the Internet connection, etc.).

Sociologists are the main contributors to the study of the social networking services in Ukraine, analyzing the phenomenon of social media, different aspects of their societal impact, individual age categories of users (especially children and adolescents), the possibility of using such services in political technology, education, etc. Periodically the media publish reviews of various quantitative technical characteristics of Internet networks, performed by IT-specialists, e.g. the Research $\&$ Branding Group study shows an overall increase in the popularity of social networking services in Ukraine, an increase in the popularity of Facebook and a loss of active VKontakte users. Typically social networks are used for communication with friends and for entertainment (Research \& Branding Group 2019). Geographical aspects in such studies are not addressed at all or shown very superficially.

On the other hand, geographers have not paid enough attention to the distribution of social networking services in Ukraine. To some extent, geographical aspects are addressed in the studies "Review of social networks and Twitter in 
Ukraine..." (Yandex 2014) and "Facebook and Instagram in Ukraine (January 2020)" - PlusOne (2020). Some researchers dealt with the spatial patterns of the use of social media during the war in Eastern Ukraine (Dobysh 2019), distribution of social network services in Volyn region (Puhach and Mytchyk 2018 and Puhach and Maister 2020), Rivne region (Puhach et al. 2020) and Ukraine (Puhach and Mytchyk 2017). However, in Ukraine there are no detailed studies of the spatial aspects of the spread of social networking services at the local level in terms of different social groups. Our research is aimed at overcoming this gap.

\section{DATA AND METHODS}

The primary data for the research was taken from the questionnaires filled by geography students from the regional centres of Western Ukraine: Lviv, Lutsk, Rivne, Uzhhorod, Ivano-Frankivsk, Ternopil and Chernivtsi. The survey was conducted in February to April 2020 using the Google Forms application. A total of 718 responses were received; among them, 687 responses were selected for further analysis, while the rest were rejected as irrelevant.

The questionnaire consisted of 14 multiple-choice questions. All questions were divided into three blocks each aimed at confirming or refuting the hypotheses set at the beginning of the study. The first block assessed the penetration rate of social networking services, the second analyzed the diversity of social networking services (in particular the number of social networking services in which the average user is registered) and the third described the everyday practices of social networking among students.

The concept of a social networking service has not been finalized: there are continuous discussions on which applications should be considered as "social". In our opinion, most applications carry signs of sociality, at least because they are used by people. Therefore, we limited the list of social networking services to "classical" applications only: Facebook, Instagram, Telegram, etc. We did not include YouTube video hosting and Viber messenger into the list of social networking services due to their widespread use, although they have all the hallmarks of social media. However, some students could indicate these and other non-listed options at own wish.

\section{RESULTS}

\section{Penetration of social networking services among the students in Western Ukraine}

The sharp dominance of three social networking services (Instagram, Telegram, Facebook) immediately catches the eye. These so-called "Big Three" cover the vast majority of students in Western Ukraine. Each of them has a penetration (coverage) rate of more than $85 \%$ of respondents. Instagram is the most popular social media among students in Western Ukraine $(95.5 \%)$. Telegram ranks second with a penetration rate of $90.0 \%$. Facebook, being the most popular social networking service on the global scale, ranks only third and is used by $85.0 \%$ of students. VKontakte, the most popular service among young people until 2017, is only in 4th position with a penetration rate of $51.5 \%$. Other social networking services are much less popular.

At large, this pattern is preserved in terms of individual administrative regions. The "Big Three" sharply dominates the rest of the social networking services. The 
largest deviations from the typical order of the less popular social networking services are observed in the Zakarpattia and Chernivtsi regions (Fig. 1).

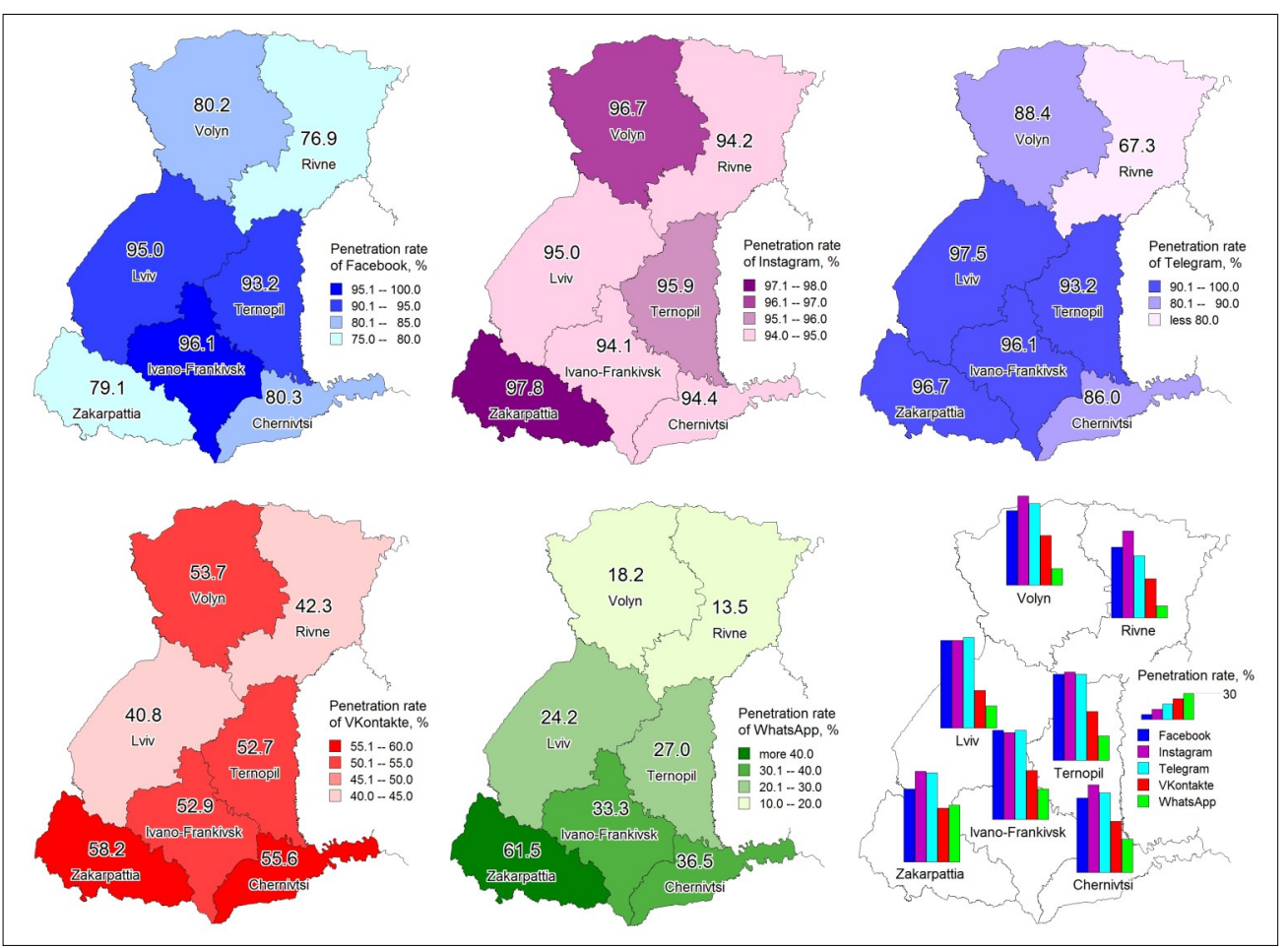

Fig. 1. Penetration rate of the main social network services among students in the regions of Western Ukraine

\section{Diversity of social networking services in the Western Ukraine}

The overall diversity coefficient for Western Ukraine is 4.0, varying from 4.3 in the Zakarpattia region to 3.3 in the Rivne region. The distribution of respondents by the number of used social media is the following: $29.8 \%$ are registered in 4 , $26.3 \%$ - in 3 and $19.4 \%$ - in 5 social networking services.

The most widespread personal list of social networking services is "Facebook, Instagram, Telegram" (18.6\%). The next typical set is "Facebook, Instagram, Telegram and VKontakte" $(15.3 \%)$. Such patterns can be traced in all regions of Western Ukraine, except Zakarpattia, where the most common sets of social networks are "Facebook, Instagram, Telegram, VKontakte and WhatsApp" and "Facebook, Instagram, Telegram, WhatsApp".

Answering the question about the most often used social networking service, $73.7 \%$ of students indicated Instagram, followed by Telegram (14.8\%), while Facebook, the largest social media in the world, was preferred only by $5.8 \%$ of respondents. These "Big Three" account for $94.3 \%$ of all preferences. The share of other social networking services is insignificant. A similar situation is observed in the context of individual regions (Tab. 1 and Fig. 2). 
GEOGRAFICKÝ ČASOPIS / GEOGRAPHICAL JOURNAL 73 (2021) 3, 283-295

Tab. 1. The most popular social networking service among students in the regions of the Western Ukraine (in \%)

\begin{tabular}{lrrrrrrrr}
\hline & $\begin{array}{c}\text { Volyn } \\
\text { region }\end{array}$ & $\begin{array}{c}\text { Zakarpattia } \\
\text { region }\end{array}$ & $\begin{array}{c}\text { Ivano- } \\
\text { Frankivsk } \\
\text { region }\end{array}$ & $\begin{array}{c}\text { Lviv } \\
\text { region }\end{array}$ & $\begin{array}{c}\text { Rivne } \\
\text { region }\end{array}$ & $\begin{array}{c}\text { Ternopil } \\
\text { region }\end{array}$ & $\begin{array}{c}\text { Chernivtsi } \\
\text { region }\end{array}$ & $\begin{array}{c}\text { Western } \\
\text { Ukraine }\end{array}$ \\
\hline Instagram & 71.9 & 78.0 & 74.5 & 75.8 & 69.2 & 81.1 & 69.1 & $\mathbf{7 3 . 7}$ \\
Telegram & 16.5 & 16.5 & 11.8 & 11.7 & 9.6 & 9.5 & 19.7 & $\mathbf{1 4 . 8}$ \\
Facebook & 4.1 & 1.1 & 3.9 & 10.0 & 15.4 & 4.1 & 5.1 & $\mathbf{5 . 8}$ \\
other & 7.4 & 4.4 & 9.8 & 2.5 & 5.8 & 5.4 & 6.2 & $\mathbf{5 . 7}$ \\
\hline
\end{tabular}

Source: own research.

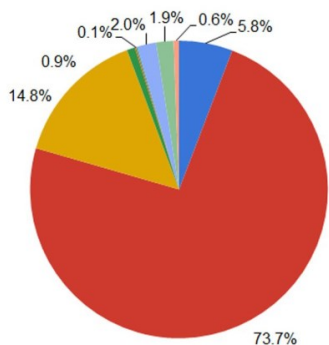

a) most often

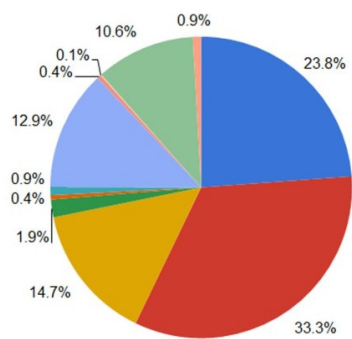

d) to communicate with people abroad

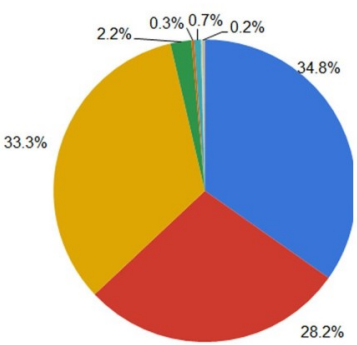

g) to read the news

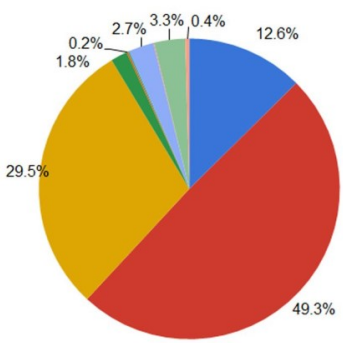

b) to communicate with friends c) to communicate with relatives

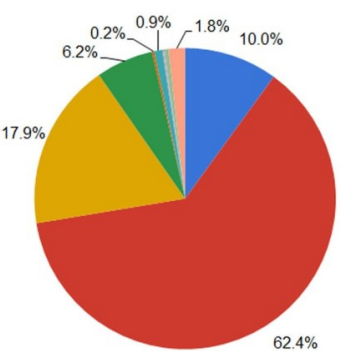

e) for entertainment

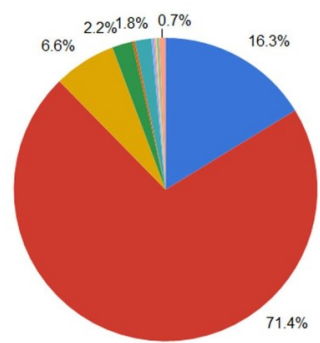

h) to create your own content
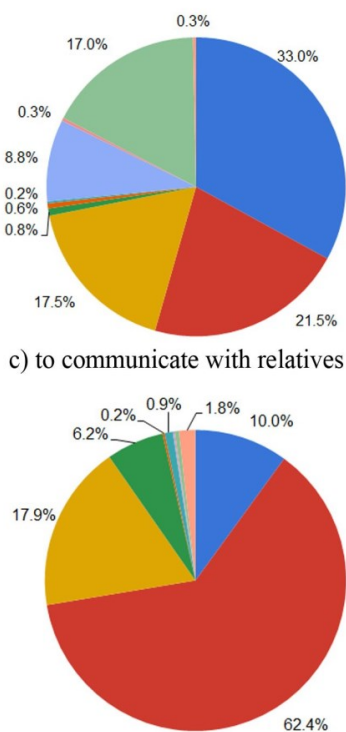

f) for learning

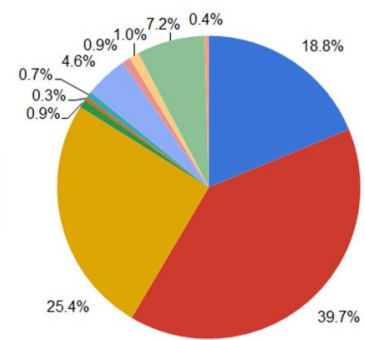

i) for work / business
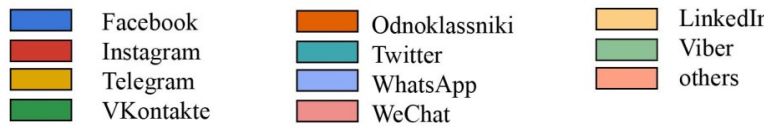

Fig. 2. Distribution of answers "Which social networking service do you use ... ?" 


\section{Everyday practices of social networking among students of Western Ukraine}

The most frequent type of social networking $(26.9 \%)$ was communication with friends, followed by entertainment/hobbies, reading news (15.9\% each), and learning (13.2\%). Approximately $10 \%$ of respondents use social networking services for communication with relatives, $8.8 \%$ create their own content and only $4.0 \%$ of students use social networking services for work and business. Almost identical patterns are observed in terms of individual regions (Tab. 2). The average deviation from the average values in Western Ukraine is only $1.2 \%$ (maximum 5.0\%).

Tab. 2. Deviations from average values in the use of social networking services by students in the regions of Western Ukraine (in \%)

\begin{tabular}{|c|c|c|c|c|c|c|c|c|}
\hline & 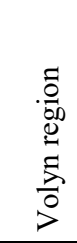 & 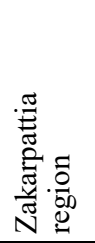 & 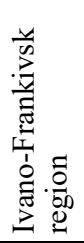 & 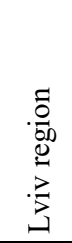 & 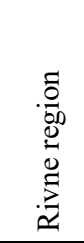 & 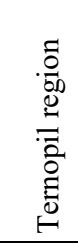 & 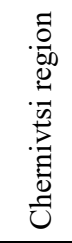 & 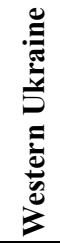 \\
\hline $\begin{array}{l}\text { Communication with } \\
\text { friends }\end{array}$ & -1.3 & 0.7 & 0.8 & -0.7 & 0.6 & 0.3 & 0.5 & 0.0 \\
\hline $\begin{array}{l}\text { Communication with } \\
\text { relatives }\end{array}$ & -0.9 & 1.8 & 0.0 & 0.9 & 1.3 & 1.6 & -2.2 & 0.0 \\
\hline Learning & -0.8 & -0.9 & 2.7 & 1.0 & 0.9 & -2.0 & 0.1 & 0.0 \\
\hline Entertainment / hobby & -0.2 & -2.9 & 1.3 & -0.2 & 0.5 & -0.1 & 1.4 & 0.0 \\
\hline Work / business & 1.4 & -1.9 & -1.2 & -0.1 & 0.3 & 1.0 & 0.1 & 0.0 \\
\hline Reading the news & -1.2 & 5.0 & -0.3 & -0.6 & -0.6 & -2.3 & -0.3 & 0.0 \\
\hline Creating own content & 2.5 & -1.2 & -1.7 & -1.6 & -1.0 & -1.1 & 1.6 & 0.0 \\
\hline $\begin{array}{l}\text { Communication with } \\
\text { people abroad }\end{array}$ & 0.6 & -0.6 & -1.6 & 1.2 & -2.0 & 2.7 & -1.2 & 0.0 \\
\hline
\end{tabular}

Source: own research.

To communicate with friends, students most often use Instagram (49.3\%). Telegram and Facebook are also popular (29.5\% and $12.6 \%$ respectively), while the share of other social networking services is insignificant. A diametrically opposite picture is observed in communication with relatives, where comparable shares of five social networking services (Facebook, Instagram, Telegram, WhatsApp, and Viber) are observed. The same social media have leading positions in communicating with people abroad (Fig. 2).

For entertainment, students use mainly Instagram, followed by Telegram, Facebook and VKontakte $(6.2 \%)$. In contrast to entertainment, students use a larger set of social media for educational purposes, including Telegram $(41.7 \%)$, as well as Facebook, Instagram and Viber. To read the news, young people actively use Facebook, Instagram, and Telegram in equal measure. The vast majority of respondents (71.4\%) chose Instagram as a social medium to create their own content. The second place $(16.3 \%)$, significantly behind the leader, belongs to Facebook, while Telegram ranks third with only $6.6 \%$. 
Only $1.0 \%$ of students use LinkedIn for work / business. This is significantly lower than in the USA (Duggan et al. 2015). Instead, we encounter the same "Big Three": Instagram (39.7\%), Telegram (25.4\%) and Facebook (18.8\%). Another point to note is the lowest percentage of students (only 70.9\%) who answered this question. To compare, $99.7 \%$ of students indicated a preferred social networking service to communicate with friends.

The structure of everyday practices of social networking was practically identical in all the regions, with only slight deviations from the average total values for Western Ukraine.

\section{DISCUSSION}

There are no significant intraregional fluctuations in the penetration and use of social networking services among students. In this sense, Western Ukraine is an integral region, where young people have similar interests, behavioral patterns and life values. However, both the overall penetration rate and structure of social media depend on historical cultural differences and geopolitical influences. In particular, specific patterns of social networking are typical for historical lands: Halychyna (Galicia), Zakarpattia (Transcarpathia), Volhynia, and Bukovina. For example the Russian social media VKontakte is more popular in Zakarpattia and Bukovina (Chernivtsi region) known for their higher tolerance to Russian cultural influences comparing with the rest of Western Ukraine. The maximum deviations of the indicators from the average values are observed in Zakarpattia, being the most distinct region in terms of natural landscapes, socio-economic and cultural traits.

Social networking is influenced by the age-specific preferences and stereotypes, as well as the interactions both within and between specific social groups. Contemporary young people prefer to work with graphics (pictures) and videos rather than with texts. Furthermore, modern smartphones are supplied with quite powerful photo and video equipment but they are not adapted to fast typing of large texts. These peculiarities have conditioned the high popularity of Instagram, focusing on the work with graphics. The relatively high popularity of Telegram among the youth is driven by its simple interface, usability, anonymity and high data protection. Young people use Instagram and Telegram to communicate with their counterparts (classmates, friends, like-minded people, alumni or former colleagues, etc.). Other studies (Research \& Branding Group 2019, Piper Sandler 2020 and PlusOne 2020) also detected the high popularity of Instagram among young people. The dominance of Instagram indicates that the most intense communication takes place within certain age groups, that is, young people communicate mostly with young people. On the contrary, the relatively low popularity of Facebook among students, being in general the most popular social networking service in Ukraine (Facebook 2020) and on a global scale (Zephoria 2020), may be explained by the complex interface and the stereotypical assessment of Facebook as a social network for seniors. However, due to the same reason, students often use Facebook to communicate with their older relatives, including international communication. The use of various social media for educational purposes is explained by the fact that teachers together with young people take part in the educational process. Since social media are a useful means of international communication, the pattern of social networking clearly reflects such specific phenomena for the Western Ukraine as mass labour migration abroad - young people use social media to keep contacts with their family members (Fedyuk and Kindler 2016). 
The results illustrate the phenomenon of multi-networking (Gillette 2015, Valentine 2017 and Barnard 2018) of contemporary students, who are not strictly tied to any particular social media, simultaneously use various social media for different purposes, and may relatively easily change them, as in the case of the Russian SNS VKontakte after the presidential ban in 2017. This shows that social networking services have already penetrated quite deeply into the everyday practices of the studied region and represent an integral part of the lives of modern youth.

Although young people today are registered on dozens of different services and platforms, there are clear trends towards the preference of certain social networking services. Also, social networks are differently used in different areas of human activity. The most popular social networking practices include communication with friends, entertainment and reading the news. These activities more and more rely on the work with multimedia rather than textual information. Contemporary young people are registered in many social networking services and need effort and time to maintain all respective profiles (Urry 2007). Accordingly, they are more likely to convey their thoughts and emotions through emojis (smilies) and pictures. The high share of students getting news from social media indicates that students in Western Ukraine are information-oriented. At the same time, the use of social networking services to get news rather than primary sources carried a threat of a "soap bubble", whereby a person perceives only what he or she likes.

On the other hand, social media are relatively rare used for learning. Such low rates can be interpreted in two ways. On the one hand, they reflect a sharp decline in the prestige of higher education in Ukraine (Osipian 2009 and Shevchenko 2019), and on the other, suggest the low activity of university teachers in social media. Social networking services have a large and not fully used potential for distance learning (Puhach and Mytchyk 2019) and can be an alternative to the online learning platforms like LMS Moodle, Office 365 Teams, Google Classroom etc. Also, we expected a higher inter-regional deviation for the work / business activities, as well as a higher share of students that actively use social media for this purpose. The reason may be the employment of students mainly in low-skilled jobs. In particular, LinkedIn, the global service for establishing business connections, is rarely used by students in Western Ukraine. To summarize, students in Western Ukraine are mostly consumers of media content, and the content created and shared by young people is mostly entertaining.

\section{CONCLUSIONS}

The research results have fully confirmed first and second research hypotheses and partially confirmed the third one. There are no significant intraregional fluctuations in the penetration and use of social networking services among students, although the pattern of social networking reflects the phantom borders of historical regions. Despite the sharp dominance of three social networking services (Instagram, Telegram and Facebook), the everyday life of students is characterized by multi-networking. The use of particular social media depends on the type of activity, age-specific preferences and stereotypes. Also, it reflects social and cultural traits of the region like mass labour migration. Although networking of the student youth in Western Ukraine generally conforms to the global and national patterns, there are some specific aspects, e.g. the relatively low use of social media in the spheres of business / work and education. 
The study of social networking services with the aid of a sociological survey is a promising research direction to investigate modern behavioural patterns of certain population groups. It makes it possible to obtain more complete information about the peculiarities of the use of different social media, as well as to investigate social networks holistically rather than consider them separately one from the other. Further research should focus on different age, social and territorial groups. In particular, it is necessary to study the peculiarities of the use of social media in rural areas and in urban settlements, in settlements according to their size (e.g. large, medium, small cities), etc.

\section{REFERENCES}

ANDRIS, C. (2016). Integrating social network data into GISystems. International Journal of Geographical Information Science, 30, 2009-2031. DOI: 10.1080/13658816. 2016.1153103.

BAILEY, M., CAO, R., KUCHLER, T., STROEBEL, J., WONG, A. (2018). Social connectedness: measurement, determinants, and effects. Journal of Economic Perspectives, 32, 259-280. DOI: $10.1257 /$ jep.32.3.259.

BARNARD, M. (2018). Designing fashion identities: The influence of social media on representation, $\mathrm{PhD}$ Thesis, Nelson Mandela University, [Online]. Available: https:// core.ac.uk/download/pdf/161850507.pdf [accessed 10 October 2020].

BINGHAM, N. (1999). Unthinkable complexity? Cyberspace otherwise. In Crang, M., Crang, P., May, J., eds. Virtual geographies. Bodies, space and relations. London (Routledge), pp. 244-260.

BORGE-HOLTHOEFER, J., RIVERO, A., GARCÍA, I., CAUHÉ, E., FERRER, A., FERRER, D., FRANCOS, D., IÑIGUEZ, D., PÉREZ, M. P., RUIZ, G., SANZ, F., SERRANO, F., VIÑAS, C., TARANCÓN, A., MOREN Y. (2011). Structural and dynamical patterns on online social networks: The Spanish May 15th Movement as a case study. PloS ONE, 6, 8, e23883. DOI: https://doi.org/10.1371/journal.pone.0023883.

CAMBRIDGE DICTIONARY (2020). Social networking, [Online]. Available: https:// dictionary.cambridge.org/dictionary/english/social-networking 12.10.2020/ [accessed 16 October 2020].

CASTELLS, M. (1996). The rise of the network society. Oxford (Blackwell).

DENYSYK, G., MEZENTSEV, K., ANTIPOVA, E., KIZIUN A. (2020). An everyday geography: Spatial diversity of the everyday life. Visnyk of $V$. N. Karazin Kharkiv National University, series "Geology. Geography. Ecology", 52, 130-138. DOI: https:// doi.org/10.26565/2410-7360-2020-52-10.

DOBYSH, M. (2019). Euromaidan and conflict in Eastern Ukraine in social networking sites: Territorial differences of pro-Russian subscriptions in Ukraine. Hungarian Geographical Bulletin, 68, 51-64. DOI: https://doi.org/10.15201/hungeobull.68.1.4.

DUGGAN, M., ELLISON, N. B., LAMPE, C., LENHART, A., MADDEN, M. (2015). Social media update 2014. While Facebook remains the most popular site, other platforms see higher rates of growth. Pew Research Center, January 9, [Online]. Available: https://www.pewresearch.org/internet/2015/01/09/social-media-update-2014/ [accessed 12 October 2020].

DULAMÃ, M. E., MAGDAŞ, I., OSACI-COSTACHE, G. (2015). Study on geography students' Internet use. Romanian review of geographical education, 4, 45-61. DOI: http://doi.org/10.23741/RRGE120154.

DULAMĀ, M. E., VESCAN, S., MAGDAŞ, I. (2016). Use of Facebook for learning and assessment in geography. Romanian Review of Geographical Education, 5, 47-66. DOI: http://doi.org/10.23741/RRGE120163.

FEDYUK, O., KINDLER, M., eds. (2016). Ukrainian migration to the European Union: Lessons from migration studies. (Springer Nature). DOI: 10.1007/978-3-319-417769_14. 
GILLETTE, S. M. (2015). Facebook's fall in the social media age. Undergraduate Theses, University of Montana, [Online]. Available: https://scholarworks.umt.edu/utpp/67 [accessed 10 October 2020].

GLÜCKLER, J., DOREIAN, P. (2016). Editorial: Social network analysis and economic geography - positional, evolutionary and multi-level approaches. Journal of Economic Geography, 16, 1123-1134. DOI: 10.1093/jeg/lbw041.

HORTON, J., KRAFTL, P. (2014). Cultural geographies. An introduction. New York (Routledge).

KELLERMAN, A. (2016). Image spaces and the geography of Internet screen-space. GeoJournal, 81, 503-517. DOI:10.1007/S10708-015-9639-1.

LANIADO, D., VOLKOVICH, Y., SCELLATO, S., MASCOLO, C., KALTENBRUNNER, A. (2017). The impact of geographic distance on online social interactions. Information Systems Frontiers, 20, 1203-1218. DOI: http://doi.org/10.1007/s10796-0179784-9.

LENGYEL, B., VARGA, A., SÁGVÁRI, B., JAKOBI, Á., KERTÉSZ, J., LENGYEL, B. (2015). Geographies of an Online Social Network. PLOS ONE , 10, 9, e0137248. DOI: https://doi.org/10.1371/journal.pone.0137248.

MENEZES, T., ROTH, C. (2017). Natural scales in geographical patterns. Scientific Reports, 7, e45823. DOI: https://doi.org/10.1038/srep45823.

MEZENTSEV, K., PROVOTAR, N., GNATIUK, O., MELNYCHUK, A., DENYSENKO, O. (2019). Ambiguous suburban spaces: trends and peculiarities of everyday practices change. Ekonomichna ta Sotsialna Geografiya, 82, 4-19. DOI: 10.17721/24137154/2019.82.4-19.

MORAN, M., SEAMAN, J., TINTI-KANE, H. (2011). Teaching, learning, and sharing: How today's higher education faculty use social media (Pearson Learning Solutions and Babson Survey Research Group), [Online]. Available: DOI: 10.17721/24137154/2019.82.4-19 [accessed 12 September 2020].

OSIPIAN, A. L. (2009). Corruption and reform in higher education in Ukraine. Comparative and International Education/Éducation Comparée et Internationale, 38, 104-122. DOI: https://doi.org/10.5206/cie-eci.v38i2.9139.

PERRIN, A. (2015). Social Networking Usage: 2005-2015. Pew Research Center, October 8, [Online]. Available: http://www.pewinternet.org/2015/10/08/2015/Social-Networking -Usage-2005-2015/ [accessed 12 September 2020].

PIPER SANDLER (2020). Piper Sandler completes 39th semi-annual Generation Z survey of 5,200 U.S. teens, [Online]. Available: http://www.pipersandler.com/3col.aspx? id $=5956$ [accessed 12 September 2020].

PLUSONE (2020). Facebook and Instagram in Ukraine (January 2020), [Online]. Available: https://plusone.com.ua/research/ [accessed 12 September 2020].

PUHACH, S., MAISTER, A. (2020). Spatial features of the distribution of social network services in Volyn region of Ukraine. Acta Geographica Silesiana, 14/2(38), 21-27.

PUHACH, S., MYTCHYK, Yu. (2017). Geography of social networking services in Ukraine. In Barsky, Yu., Puhach, S., eds. Human geographical factors of regional development. Proceedings of Conference, Lutsk, 6-7 April 2017. Lutsk (PP Ivanyuk V.P.), pp. 99-101.

PUHACH, S., MYTCHYK, Yu. (2018). Spatial analysis of social networking services in the Volyn region. Ekonomichna ta Sotsialna Geografiya, 79, 14-21. DOI: https:// doi.org/10.17721/2413-7154/2018.79.14-21.

PUHACH, S., MYTCHYK, Yu. (2019). Facebook as an alternative to Moodle in distance learning. In Barsky, Yu., Puhach, S., eds. Human geographical factors of regional development. Proceedings of Conference, Lutsk, 11-12 April 2019. Lutsk (PP Ivanyuk V.P.), pp. 187-190.

PUHACH, S., POHREBSKYI, T., GOLUB, G. (2020). Spatial peculiarities of social networking services distribution in Rivnenska oblast. Human Geography Journal, 28, $43-$ 50. DOI: https://doi.org/10.26565/2076-1333-2020-28-05. 
RESEARCH \& BRANDING GROUP (2019). The practice of using social networks in Ukraine, [Online]. Available: http://rb.com.ua/blog/praktika-polzovanija-socsetjami-vukraine/ [accessed 12 September 2020].

SHEVCHENKO, V. V. (2019). The reform of the higher education of Ukraine in the conditions of the military-political crisis. International Journal of Educational Development, 65, 237-253. DOI: https://doi.org/10.1016/j.ijedudev.2018.08.009.

SUI, D., GOODCHILD, M. (2011). The convergence of GIS and social media: Challenges for GIScience. International Journal of Geographical Information Science, 25, $1737-$ 1748. DOI: https://doi.org/10.1080/13658816.2011.604636.

TAKHTEYEV, Y., GRUZD, A., WELLMAN, B. (2012). Geography of Twitter networks. Social Networks, 34, 1, 73-81. DOI: https://doi.org/10.1016/j.socnet.2011.05.006.

TER WAL, A., BOSCHMA, R. (2009). Applying social network analysis in economic geography: Framing some key analytic issues. The Annals of Regional Science, 43, 739 756. DOI: $10.1007 / \mathrm{s} 00168-008-0258-3$.

URRY, J. (2007). Mobilities. Cambridge (Polity Press Ltd.).

VALENTINE, O. (2017). Multi-networking approaches its peak, [Online]. Available: https://blog.globalwebindex.com/chart-of-the-day/multi-networ king-approaches-itspeak/ [accessed 10 October 2020].

YANDEX (2014). Review of Social Networking Services and Twitter in Ukraine according to Yandex Blog Search, $2013-2014$, [Online]. Available: https://cacheman01i.cdn.yandex.net/download.yandex.ru/company/Yandex_on_UkrainianSMM Summer 2014.pdf. [accessed 10 February 2017].

ZEPHORIA (2020). The Top 20 Valuable Facebook Statistics - Updated July 2020, [Online]. Available: https://zephoria.com/top-15-valuable-facebook-statistics [accessed 3 August 2020].

https://www.facebook.com

Serhii Puhach, Kostyantyn Mez ents ev, Oleksiy Gnatiuk

\section{SOCIÁLNE SIETE V KAŽDODENNOM ŽIVOTE ŠTUDENTOV NA ZÁPADNEJ UKRAJINE}

Tradičný empirický výskum sociálnych médií naráža na nedostupnost’ rozsiahleho a reprezentatívneho súboru údajov o využívaní služieb sociálnych sietí rôznymi vekovými, sociálnymi alebo územnými skupinami. Stúdium služieb sociálnych sietí pomocou sociologického prieskumu predstavuje perspektívny smer výskumu súčasných vzorcov správania určitých skupín obyvatel'stva. Umožňuje nám získat' kompletnejšie informácie o zvláštnostiach použivania rôznych sociálnych médií, ako aj skúmat' sociálne siete holisticky a neposudzovat' ich oddelene od seba.

Primárne údaje pre výskum boli získané z dotazníkov, ktoré vyplnili študenti geografie z regionálnych centier západnej Ukrajiny. Prieskum sa uskutočnil na jar roku 2020 pomocou aplikácie Formuláre Google. Dotazník pozostával zo 14 otázok s možnost'ou výberu $\mathrm{z}$ viacerých odpovedỉ, ktoré boli rozdelené do troch blokov, pričom každý z nich bol zameraný na potvrdenie alebo vyvrátenie hypotézy stanovenej na začiatku štúdie. Prvý blok hodnotil rozšírenia služieb sociálnych sietí, druhý analyzoval rozmanitost' týchto služieb a tretí sa zameriaval na každodenné aktivity študentov na sociálnych siet’ach. Celkovo sa nám podarilo získat' 718 odpovedí, z ktorých 687 bolo vybraných na d’alšiu analýzu.

Výsledky výskumu čiastočne potvrdili počiatočné hypotézy. Najmä to, že neexistujú žiadne významné medziregionálne rozdiely v rozšírení a využívaní služieb sociálnych sietí medzi študentmi. Na druhej strane sme zistili výraznú dominanciu služieb troch sociálnych sietí: Instagram, Telegram a Facebook. Rôznorodost' služieb sociálnych sietí je podmienená na jednej strane osobitost'ami každodenných 
aktivít študentov a na strane druhej miestnymi podmienkami: poloha voči hraniciam, štruktúra sídelného systému, podiel vidieckeho obyvatel'stva atd'. Každodenný život študentov je charakterizovaný mnohonásobným siet’ovaním (multi-networking): nie sú viazaní na jednu konkrétnu službu, relatívne lahko menia sociálne médiá, pričom využívajú rôzne služby sociálnych sietí na rozličné účely. Vnútroregionálne rozdiely vo využívaní služieb sociálnych sietí študentmi v rôznych sférach každodenného života sú najvýznamnejšie z hl’adiska vytvárania vlastného obsahu, čítania spravodajstva a komunikácie s l’ud'mi v zahraničí. Najmenšie odchýlky od priemerných hodnôt boli zistené pri komunikácii s priatel'mi. Pravdepodobne v dôsledku zamestnávania študentov hlavne v nižšie kvalifikovaných zamestnaniach sme nezistili očakávanú vysokú odchýlku pri analýze pracovných a podnikatel'ských aktivít študentov.

(c) (i) Article first received: December 2020

Article accepted: August 2021 
